\title{
ARCHITECTURAL COMPETITIONS AS AN INSTRUMENT FOR HERITAGE PROTECTION: THE DYNAMICS OF COMPETITION TAXONOMY
}

\author{
Ilze MIKELSONE \\ Rigas Tehniska universitate, Azenes iela 18, LV-1658, Riga, Latvia \\ E-mail: ilze@taktila.lv
}

Received 29 February 2016; accepted 31 August 2016

\begin{abstract}
Various concepts of preserving the cultural and historical environment of the Historical centre of Riga have been documented within the last century period, including the international status as item No. 852 on the UNESCO World heritage list. The Riga Historical Centre Preservation and Protection Law was created as one of the mechanisms for the preservation of the status, which, among other notions, makes the procedure of architectural competitions mandatory. The territory, being part of the list, contains listings that it should consider in terms of value. Under such context the competition not only determines the competition for the best and serves as formal instrument for hindering hasty or inappropriate development, but also is public interpretation of the contemporary architectural values in contra dictionary aspects. The purpose is to analyse the structure of competition procedure instrument and relation to the specifics of the heritage and contemporary challenges. The study uses 75 competitions briefs and jury protocols proceeding in period 2004-2014, in the territory of urban heritage. The results demonstrate taxonomy ${ }^{1}$ of systemic listings of architectural properties followed by expert voting form as the main mechanism for results.
\end{abstract}

Keywords: architectural competition, heritage protection, Riga Historical Centre, assessment methodology.

\section{Introduction}

The mechanisms of sustaining, preserving and developing of the past built environment are popular in the entire Europe and discourse is often being evoked together with the ageing society and shrinking cities. The rich historical heritage, preservation of which is prescribed by the law, deals with continuously upcoming material of timeline and also includes controversial discussions about ambiguous value phantom. Topics on assignment of meaning, followed by obsession with censorship and confident wish to protect anything that has been created in the past - both the valuable conceptions and the failures, is often criticized in the local press scene, even pointing out that "the most contemporary architecture of the 21st century is the heritage of the past" (Budže 2014). Besides, the criticism and debates about "simplification of history", "search for authenticity", "architect's egos" and other expressed verdicts around this topic, the context differs in the post-Soviet space. Since various processes have been taking chaotic, irregular development, the threat of the

\footnotetext{
${ }^{1}$ principles and methods of classification and nomenclature of organized hierarchic systems.
}

heritage loss has seriously competed with the threat of stagnation by excessive conservation.

In the capital of Latvia - Riga - heritage agenda brightly concerns the special territory around city centre, which is characterized by the precedent of internationally recognized valuable space and complementary aspects - small professional community and high bureaucratic culture. The development of the territory is also haltered by several significant challenges. Besides chain of challenges within average contemporary urban developments, the city has to deal with maintenance of the assigned status and concepts of conservation (Ameloskina 2008). It has to remain balance within the neoliberal development in post-soviet space processes and the lowest price procurement law. It supposes to challenge attempts improve the quality of the built environment standards of today and of the future, ensuring that urban sustainability is integral component of its urban development attitude. Popular instruments to express the specific care of "valuable" architecture is not only the listing and hierarchy of the criteria's, but also legally and practically inwrought mechanisms, referable for implementing new architecture in special territory. 


\section{The context}

In the context of heritage and competition in Riga Historical Center (hereinafter - RHC) several characteristic issues should be pointed out as accents. Firstly, this territory has been also a highly functional centre in terms of financial, economical and cultural activities, which is not so worldwide obvious heritage standard (Cinis, Dambis 2003). Consequently, the attempts to develop different investments there have been very notable. Secondly, the average size of other world build heritage sites globally in comparison to RHC and its protection zone are mostly smaller (Salmon 2016). The territory with protection encumbrance is heterogeneous and thus protection dilemma becomes contra dictionary. In this case, the awarded status forms a single, uniform body, which otherwise would be tumultuous and unorganized. The heritage metaphor and its preservation tend to be attributed not only for the purpose of describing the achievable parameters of an individual building alone, but for describing the whole territory, social processes and cultural phenomena. Thirdly, one of the hotspots of Latvia's internal politics has always been the topic of public relationship between the capital and the state (Cinis, Dambis 2003).

The civil institution that implements the state control on the protection of cultural monuments functions under the supervision of Ministry of Culture. Responsibility about built heritage in the local strategic documents starts with the following citation, "the historic centre of Riga is a bright illustration of European history. Throughout the centuries, Riga has been the centre of various significant events and has served as a point of intersection for the European peoples' contacts. To this day, Riga serves as an evidence of the impact of European cultural space on ur-

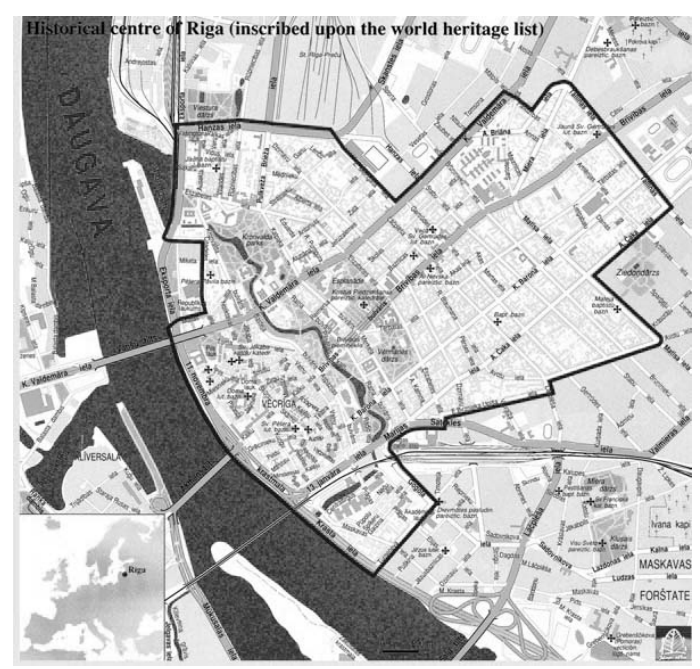

Fig. 1. Historical centre of Riga as the World cultural heritage site (Lejnieks et al. 2015) ban historical development as well as commercial and cultural routes between the East and the West. Riga has always followed the current trends in architecture and urban planning at the same time preserving the urban spatial unity, and thus, creating high-quality cultural environment." (State Inspection for Heritage Protection 2015a).

Since the international recognition of inscribed property granted to Riga's urban environment in 1997, manifested by the place No. 852 in the World Cultural Heritage list of the United Nations Educational, Scientific and Cultural Organization (UNESCO) Riga historical centre and its protection zone (WHC 1997), the framework of the regulatory enactments in regard to control of its development, protection and series of relevant regulations has substantially increased (Saeima 2003; State Inspection for Heritage Protection 2014). The territory of RHC occupies 435 hectares or $1.4 \%$ of the city territory, and accommodates around 4000 buildings (State Inspection for Heritage Protection 2015a). It is constituted by a "rather well preserved medieval and later period city structure, having considerable universal value, and it is formed by medieval buildings, volume and quality of Art Noveau architecture not found elsewhere in the world, as well as the 19th century wooden architecture" (Figs 1-2).

The wider contexts of research are implementation of generally accepted values in the cultural and historical heritage territories, tackled by contemporary challenges (Fig. 3). In this study the competition is not viewed as the subject "of innovation, public attention, discovery of a talent or for the findings of the best between ...", but rather as a tool to achieve quality of the perspective spatial environment in certain places, which have been granted special importance by the law.

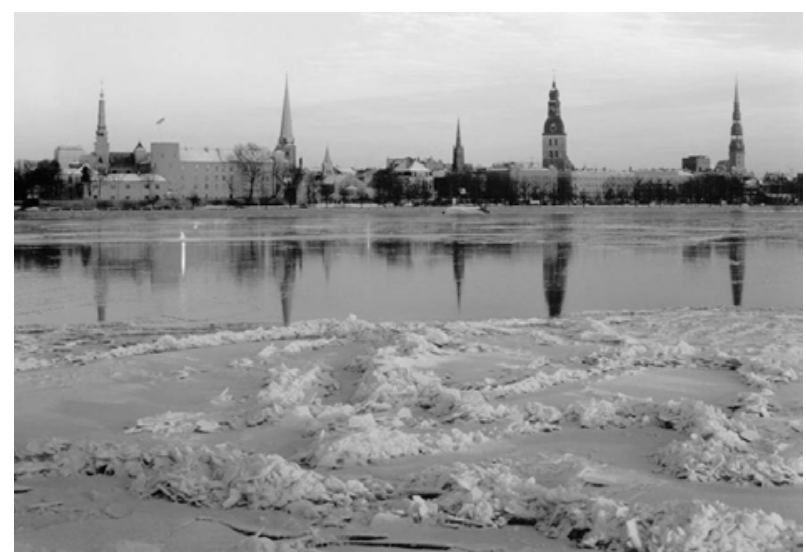

Fig. 2. Silhouette of Riga as European landmark (Lejnieks et al. 2015) 


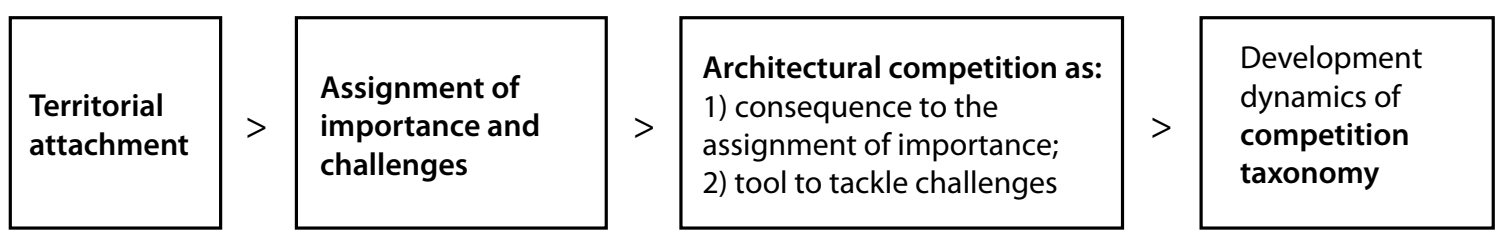

Fig. 3. The wider contexts of research are implementation of generally accepted values in the cultural and historical heritage territories are questioned as effective and dynamic, by author

In accordance with the terminology of regulatory, enactments transformation of the cultural and historical environment is "any technical, constructive, economic activity, which results in physical changes of the cultural and historical environment (its function, form, color, individual details, material), as well as other cultural value" (Saeima 2003). Accordingly, resource-intensive procedures are specified before this physical replacement happens. By the main idea, these procedures should give assurance of improving quality of the perspective product - the building. One of the tools being used is the procedure of the mandatory competition. Since the main instrument in environment evaluation and analysis rests on the criteria hierarchy, research questions the clarity, intelligibility and approbation of criteria by which architectural heritage protection has been achieved. Expanding the architectural competition subject in the heritage context to competition procedure subject, the objective of the study is the dynamics of competition taxonomy in the heritage places, in the period of decade.

\section{General regulations of the research}

This paper research field comprises copies of selected 75 competition briefs and their protocols (all available to the author), which have taken place in the territory of the RHC during the period of 2004-2014, and which is considered to be a sufficient amount to allow drawing conclusions on the specified research issues. In this study nine functional typologies have been analyzed for the architectural competition in the aforementioned territory and time period: 1) Development of urban planning and districts $-5 / 75 ; 2$ ) Residential buildings - 28/75; 3) Multifunctional buildings - 22; 4) Commercial buildings (commercial institutions, banks, offices) - 8/75; 5) Administrative and management buildings $-2 / 75 ; 6$ ) Culture buildings (museums, cinemas, theatres, concert halls) - 3/75; 7) Hotels $2 / 75$; 8) Communication institutions, transport and public utility (railroad stations, parking lots) - 2/75; 9) Public space- (environmental objects, squares, promenades) $-3 / 75$.

The number distribution between years relates economical activity processes, as following: 2004 (9cases); 2005 (19 cases); 2006 (16 cases); 2007(13 cases); 2008 (3 cases); 2009 (3cases); 2010 ( 3 cases); 2011 (3 cases); 2012 ( 2 cases); 2013 ( 2 cases); 2014 ( 2 cases).

The competitions were most often initiated by a private investor (Limited liability Company), often these were construction companies as well. Competitions have been initiated also by state and municipal institutions (Riga City Council, SJSC State Real Estate or other

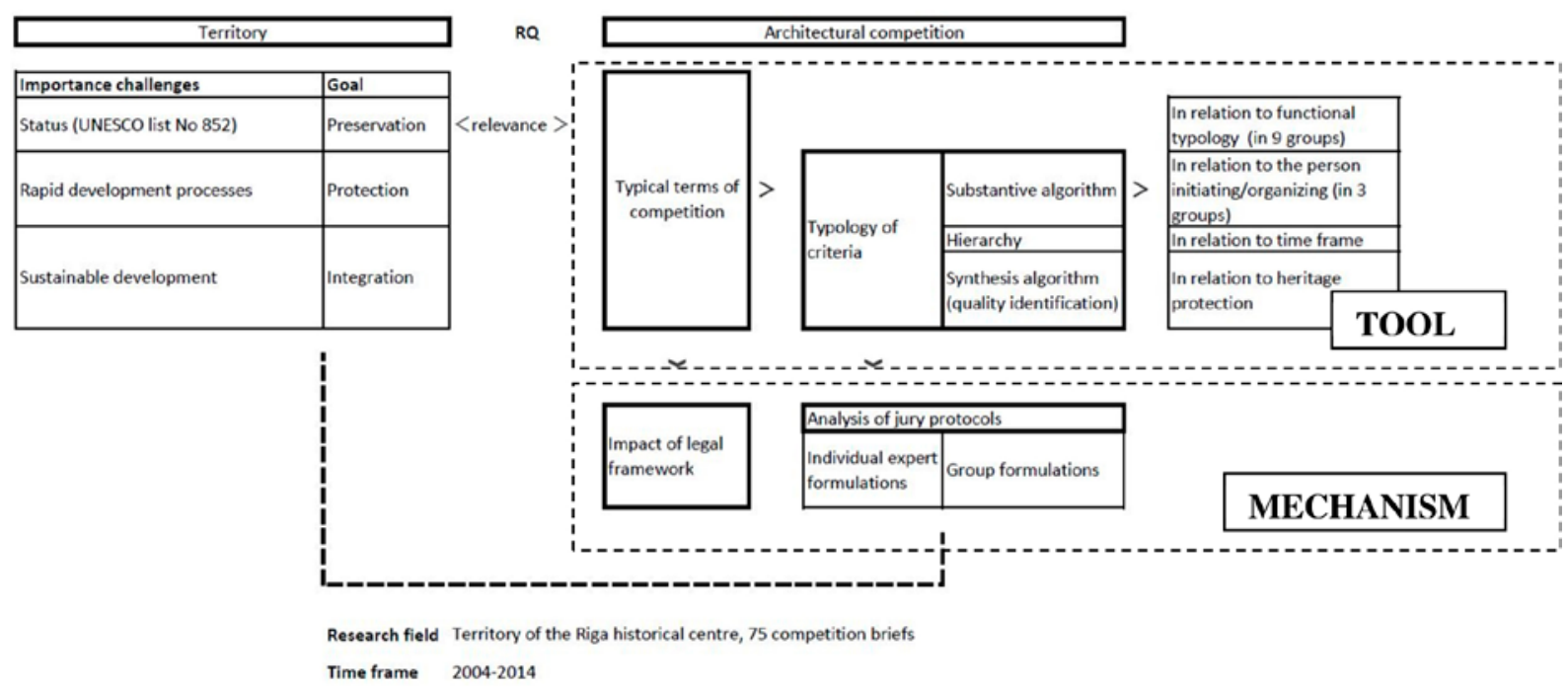

Fig. 4. The research tasks and methodological outlines, by author 
public institutions, as Representative of the European Commission in Latvia, etc.). Most often, though not always the competition procedure has been organized by the Latvian Association of Architects upon the initiative of the client.

Research methodology differ tool (competition procedure standard and criteria) and mechanism (legislation and evaluation in competition procedure) categories (Fig. 4) to be further analyzed. The taxonomy in the context of tool in the statutory architectural competitions was analyzed in categories, related to typical parts in competition briefs, aim and criteria relevance.

The taxonomy in the context of mechanism in the statutory architectural competitions was analyzed in categories, related to impacts of legislation and jury actions. The research tasks are following: 1) to analyze the context of contemporary challenges in value set agreements; 2 ) to gather information on general taxonomy, criteria models and algorithms used in the competition briefs; 1) to gather the binding regulatory enactments stipulated by the law of the Republic of Latvia; 2) to perform qualitative evaluation of the jury protocols, especially under the context of the criteria; 3 ) to diagnose criteria typology in relevance of challenge categories (Fig. 4).

The results include information about competition taxonomy in the following relevance of 1 ) general conclusions on any changes over the time period; 2 ) the purpose and impact of legislation; 3 ) the relevance to functional typology; 4) the relevance to person initiating/organizing competition; 5) other findings.

\section{Previous research on the subject}

In the context of generally accepted values, the question of what is a contemporary criteria in architecture is so vast and multifaceted that first of all requires to distinguish the subjects, to which the criteria is being attributed and ways how it can be expressed. Numbers of studies have been made on methods for determining architectural value, value of the cultural and historical object and the value of the competition object (Volker 2010a, 2010b). Under the context of heritage value between other values is analysed in the study of another local heritage-listing applicant of UNESCO, the town Kuldiga (Jākobsone 2011) Recently, the study "Riga World Heritage site impact evaluation method" has been conducted in 2013 under the commission of the municipality, analysing in detail the methods of qualitative evaluation of the experts regarding the completed transformations of the buildings (Kārkliņš 2013).

In the perspective of architectural competition as the contest itself, the positive and negative aspects have been collected by Portuguese researcher P. Guilherme by the documentations of P. Spreiregen, J. Strong, J. Nasar and G. S. Collyer (Guilherme 2014). Conclusion was that positive aspects can be grouped as 1) the discovery and presentation of (new/old) talent; 2 ) the production of quality architecture and new solutions; 3 ) to provide attention, marketing or publicizing architecture (and the architect), but, the negative aspects can be grouped as: 1) competition structure and procedures; 2) jury's assessments, representativeness, autonomy, impartiality, ethics and credibility; 3) extensive use of human resources, time expenditure, creativity and financial resources allocated to competitions by everyone, particularly architects. Obvious is the positive aspect's belonging to expected gains, and also obvious is negative aspect's belonging to the procedure and expenses. In the context of competition procedure as mechanism for preservation and conservation none of the aspects is mentioned.

Studies of architectural competitions have been conducted from various angles in Netherlands (Volker et al. 2008; Volker 2010a, 2010b), Sweden (Ronn 2011, 2014), Denmark (Kreiner 2010), Finland (Ronn, Kazemian 2007) and Belgium (Menon, Vandenburgh 2014). Particularly, in the perspective or architectural quality, Swedish publicist Magnuss Ronn, as outcome of a comprehensive study of architectural competitions in the Nordic countries (1999-2000) through a dialogue based assessment of architecture and urban design projects by 18 highly qualified experts, has condensed five quality identifying perception concepts, as: 1) Vitruvius formula venustas-utilitas-firmitas; 2) Context; 3) Wholeness; 4) Contemporariness; 5) Usability. In this regard, several other researchers have noted, that competition procedure is also "an arena for an intellectual process of verbalizing the unverbalized and the obscurely thought: architectural competitions can be seen as discursive events" (Andersson 2014), whereas the outcome is uncertain.

Besides theoretical and practical viewpoints, also social network plays increasingly big role in the statutory defined competition procedures. Authorities, attitudes and relations of the involved parties, in a distinctively systemic manner have being analysed in the Belgium architectural contest model and case study (Menon, Vandenburgh 2014) in accordance with the approach of Actor Network theory by Bruno Latour. The authors have conducted a study of who-or-what is the winner of architectural competition. It demonstrates the idea, that architectural competitions are more than just client-program-architect. The conclusions of the article emphasize particular role played by the brief, and strong interaction between the winning entry and "the modes of representation". 
However, competitions as well as awards in the evaluation of heritage and particularly the architectural heritage seem to be separate group in the conclusionary discussions organised by the public sector. Until 2013 a common archive for the terms of competition or their results has not existed in Latvia. Extensive quantitative research regarding competitions in Latvia has been recently conducted by Riga Technical university doctoral student L. Leitāne-Šmīdberga. Based on library of competition data collected on competitions within period 1991-2013 the available information on 320 objects Riga and its historical centre territory has been summarized in 14 categories (Leitāne-Šmīdberga 2015).

When describing modern taxonomy, concept of listing introduces an order, series of more or less differing subjects, placed within the same context or viewed from the same perspective (Eko 2009). Definitions provided in regard to architecture and urban environment are also mostly listings, of problems, challenges, qualities and other objectives. The public representation of architecture often includes rephrased and interpreted properties of Vitruvius Triad, adding everything what could possibly be important. A holistic sustainability approach-tool, where sustainability is evaluated and presented in the form of a value map foresees the methodology to render explicit the fundamental links between ecology, economy and society (Butters 2011; UNESCO 2011). This management of cultural heritage resources at different urban levels is example of the listing concept in systemic approach (Fig. 5). Since sustainable design is also contextual and process orientated, in practical design evaluation it might lose borders. Due to problematic of immeasurability of adjectives (for example, creativity, efficiency); insufficient resources for qualitative evaluation; multiple level understanding of key-concepts (what is creativity) and competition between incompatible and hardly compatible criteria (energy creativity vs. efficiency), in practical utilization

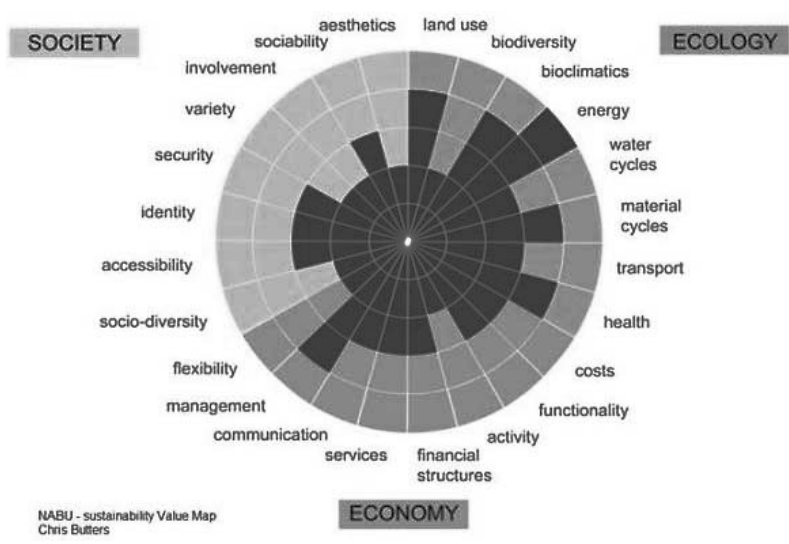

Fig. 5. Example of the listing concept in systemic approach. NABU-Sustainability Value Map, by Chris Butters (UNESCO 2011) panoramas and barometers becomes either a cast or hard multilevel compromise. Still, improvised panoramic listings remain popular assessment instrument.

The Architects' Council of Europe (ACE), The International Union of Architects (UIA) and the Latvian association of Architects (LAoA) have synchronized the master documents with guidelines and recommendations for an Architectural Design Contest, distinguishing lists of urban, architectural, functional, ecological and economic criteria groups. By zooming the evaluation subject in wider context, revealed that most assessment systems, particularly the first developed in the 1990s, where originally devised to evaluate new buildings after their completion, while nowadays target values are also advised to implement in the planning as early as possible (Drexler, El Khouli 2012). Evaluation systems are classified into three basic categories: descriptive, quantitative and qualitative, where Design Contest profile mostly refers to the first. While the criteria frame within listing concept is clear, researchers on the subject of Architectural Design Contest often are pointing out series of problems particularly in the context of public interpretation of architectural quality. Subject cases are characterised by two forms of taxonomy, the presence of lists (fulfilling demand, criteria, normative acts, expert nomenclature, etc.) and consensus of the relevant experts as the leading method for finding the winner.

\section{The results of the research in the tool category}

The aim, demands and criteria are the three characteristic tools for the implementation of value set agreements in typical competition brief, determining essential characteristic, which distinguishes or isolates features that cause making the choice in favour one or the other architectural solution. The aim of the competition is most often formulated as "to obtain 1) high quality design proposal in terms of urban construction, architecture and functionality for the building conception, in accordance with the requirements resulting from the regulations on the use and construction in the territory of Riga (RDPAD 2003); 2) the best possible solution, ensuring rational use of funds, unrestricted competition among bidders, as well as equal and fair treatment of them".

The analysis of 75 competition briefs during decade show that typical competition brief, with different quality options, contains four parts:

- Invitation (Organizers and nature of the competition; Eligibility; Prizes and purchases; Jury; Approval of the competition program; Delivery of the program documentation; Competition language; Duration of the competition; etc.); 
- Technical information (Documentation; Questions; Judging the competition, and publication and exhibition of the results; Further action as a result of the competition; User rights to the competition proposals; Rules of the competition; etc.);

- The competition assignment (Background to the assignment; The competition area; Aims of the competition; Instructions for parking, infrastructure, cost targets, other binding parameters; Jury work; Judging criteria; etc.);

- Instructions for drawing up the entries (Required documents and method of presentation; Anonymity; Submission of entries).

Participation in the competition is most often specified as "equally freely available to all legal and physical entities". Such conditions of bidder selection, where the bidder has to meet the imposed qualification requirements: having achieved a certain turnover, having accumulated certain experience with completed construction objects or having relevant certificates, is not characteristic of the RHC competition briefs.

\section{Typology of criteria}

Accordingly, the aim of average brief characterizes quality in three aspects, the right and good quality (Ronn 2014), and the forecast able benefit quality. First concentrates on demands of evaluating the fulfilment of the procedure and requirements, where essentially the conformity of the technical proposal to the requirements of the terms of competition is evaluated. (A and B in Fig. 6). Second group relate to criterion of evaluating of the architectural proposal (C in Fig. 6). The third group - "rational use of funds" (D in Fig. 6) is one of the most qualitatively expanding criterion in the reviewed briefs and concerns the price of the project, the price per square meter, the organizational management and planning, the timing, etc.

Since aim formulations "free competition among bidders" and "fair and equal treatment" strongly respond competence and morality of the organizer and jury, they were not further analyzed. Research has mainly concentrated on detecting criterion belonging to A, B, C and D groups. Beside the fact, that in most cases criterions were repeated, messy organized, differently formulated, and individually replenished, the results show, that criterion conformity to the groups is absolutely accurate. Summary of formulations, based on the data is shown in Figure 7.

Besides evaluation credentials, substantial majority adds the following instructions to the evaluation criteria of the terms of tender: "Before beginning its work, the Jury has made available to it the recommendations of the client and competition organisers"; "The Jury must review the projects that do not comply with the instructions and decide to disqualify or not, the candidate(s) concerned. Under no circumstances may the Jury examine any extra documents not provided for in these rules"; "During the judging session, the Jury evaluates entries according to: (versions of Fig. 7)"; and "The Jury shall have a right to specify the set criteria, defining them more precisely or choosing some additional criteria. The Jury shall have a right to invite independent experts for assistance in evaluation of the submitted proposals".

The forms of decision making have been organized mainly by voting (73/75), but there is also the case of predefined calculation algorithm (2/75). The amount of remuneration strongly differs. The amount of available time frame also differs.
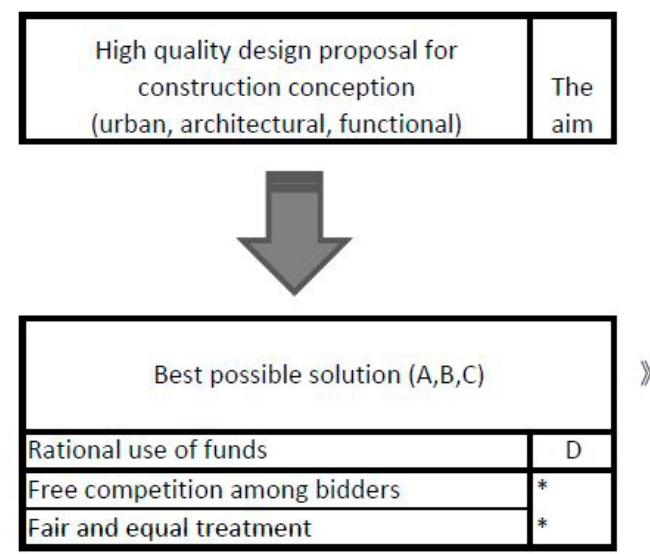

* Competence of the organizer and jury

\begin{tabular}{|l|l|}
\hline Conformity to construction regulations & A \\
\hline Quality of fulfilment of conditions & B \\
\hline Architectural quality & C \\
\hline
\end{tabular}

Fig. 6. Criteria groups in accordance with a typical formulation of competition objectives, by author 


\begin{tabular}{|c|c|c|c|}
\hline Group & Conditions of objective & Sub-group & Frequently used formulations \\
\hline A & $\begin{array}{l}\text { Confirmity of the object to the regulatory } \\
\text { enactments regulating construction in } \\
\text { Riga }\end{array}$ & & \\
\hline B & $\begin{array}{l}\text { Conformity to the requirements of the } \\
\text { terms of competition and program } \\
\text { specified in the terms of competition and } \\
\text { technical specification }\end{array}$ & & \\
\hline \multirow{8}{*}{ C } & \multirow{8}{*}{ Architectural quality } & C1 & $\begin{array}{l}\text { Compatibility of the object with the urban construction environment } \\
\text { and integration of the building volume in the environmental context }\end{array}$ \\
\hline & & C2 & $\begin{array}{l}\text { Architectural quality of the solution (functionality of the building } \\
\text { layout and expressiveness of the silhouette) or (functionality of the } \\
\text { building layout, expressiveness of volume and facades) }\end{array}$ \\
\hline & & C3 & $\begin{array}{l}\text { Stuctural solution; Technical feasibility of the design; proposal of } \\
\text { technical quality of the building to be designed }\end{array}$ \\
\hline & & C4 & $\begin{array}{l}\text { Energy efficiency and sustainability of the concept (green, self- } \\
\text { sufficient house); Functional solution (considering the ecological } \\
\text { quality of the environment and traffic concept) }\end{array}$ \\
\hline & & C5 & Environmental accessibility \\
\hline & & C6 & Attention paid to the ratio of residential and other functions \\
\hline & & C7 & Freshness of the idea or the imagery \\
\hline & & C8 & Innovative aspects included in the design \\
\hline \multirow{5}{*}{ D } & \multirow{5}{*}{ Rational use of funds } & D1 & Construction costs \\
\hline & & D2 & $\begin{array}{l}\text { Technical parameters of the design; costs of } \\
\text { efficient/rentable/sellable areas; efficiency of space use; possibility } \\
\text { of implementing of the potential of residential and commercial } \\
\text { premises; scope of residential premises }\end{array}$ \\
\hline & & D3 & $\begin{array}{l}\text { Estimated design costs; economic justification (costs and terms of } \\
\text { sketch and technical design); use of maximum construction density } \\
\text { and intensity in accordance with the Architectural planning task; } \\
\text { have to find balance between the maximum possible construction } \\
\text { area and the architectural ensemble of the historical city centre }\end{array}$ \\
\hline & & D4 & $\begin{array}{l}\text { Expected time schedule for development and approval of sketch and } \\
\text { technical design; proposed construction design completion term; } \\
\text { term including all required approvals and Construction Board } \\
\text { acceptance; expected author supervision costs; costs indicating } \\
\text { currency and taxes }\end{array}$ \\
\hline & & D5 & Work performance organization and methods \\
\hline
\end{tabular}

Fig. 7. Summarized nomenclature of criteria groups and sub-groups in accordance with the most frequently used formulations, by author

\section{The results of the research in the mechanism category}

The context of the regulatory enactments and expert jury activities are the two detected most characteristic mechanisms for the implementation of value set agreements in competition. Since regaining of independence during the time period from 1990 until today systematic and sometimes very rapid development has taken place in the construction environment of Riga. Optional mandatory requirement to apply the architectural competition procedure in special territories of the capital has been imposed by the municipal regulatory enactments already in 1993 , where it has been defined with the note that "the City Board shall be entitled to decide" whether to apply it or not. Since then both mechanisms have developed to be served as solution to the public discontent and discussion on the new architecture, reconstruction, urban environment projects and development model of the cultural and historical environment in general. 


\begin{tabular}{|c|c|c|c|c|}
\hline $\begin{array}{l}\text { Status of regulatory } \\
\text { enactment }\end{array}$ & Code & Year & Essence of regulatory enactment & Impact on competition procedure \\
\hline $\begin{array}{l}\text { Municipal } \\
\text { regulations }\end{array}$ & Riga City Council decision No. 97, 2.9 & 1993 & $\begin{array}{l}\text { Concerning procedure of implementation of } \\
\text { development proposals in Riga }\end{array}$ & $\begin{array}{l}\text { Determines the case of application of } \\
\text { competition procedure }\end{array}$ \\
\hline Regulations & Cabinet Regulations of the Republic of Latvia No. 324 & $\begin{array}{l}(1995) \\
2000\end{array}$ & $\begin{array}{l}\text { Regulations on the procedure of organization of } \\
\text { building design and territorial planning design } \\
\text { competitions }\end{array}$ & $\begin{array}{l}\text { On the procedure and content of } \\
\text { competition }\end{array}$ \\
\hline $\begin{array}{l}\text { Municipal } \\
\text { regulations }\end{array}$ & Riga territorial plan 2006-2018 (hereinafter - TIAN) & 2006 & In Riga, in special cases & $\begin{array}{l}\text { Determines the case of application of } \\
\text { competition procedure }\end{array}$ \\
\hline $\begin{array}{l}\text { Municipal } \\
\text { regulations }\end{array}$ & $\begin{array}{l}\text { Plan of the Riga historical centre and its protection zone } \\
\text { (hereinafter - RVC AZ TIAN) binding regulations No. } 38 \text { of } \\
\text { the Riga City Council "Regulations on use and } \\
\text { construction of the Riga historical centre and its } \\
\text { protection zone of } 07.02 .2006 \text { " }\end{array}$ & 2006 & $\begin{array}{l}\text { Plan of the Riga historical centre and its protection } \\
\text { zone }\end{array}$ & $\begin{array}{l}\text { Determines the case of application of } \\
\text { competition procedure }\end{array}$ \\
\hline Law & Law on the Historic Centre of Riga, Section 14 & 2004 & $\begin{array}{l}\text { Construction of new buildings in the public external } \\
\text { space of RVC shall be permitted only after } \\
\text { obtaining of designs through open architectural } \\
\text { competitions, their public evaluation and } \\
\text { consideration at the council and approval in } \\
\text { accordance with the procedure specified in the } \\
\text { regulatory enactments with the State Inspectorate } \\
\text { of Heritage Protection }\end{array}$ & $\begin{array}{l}\text { On the procedure and content of } \\
\text { competition }\end{array}$ \\
\hline Regulations & $\begin{array}{l}\text { Cabinet Regulations of the Republic of Latvia No. } 90 \text {, } \\
\text { issued in accordance with Paragraph V of Section } 22 \text { of } \\
\text { the law "On the Procurement for State of Municipal } \\
\text { Needs" }\end{array}$ & 2004 & $\begin{array}{l}\text { Regulations on proceedings of the design sketch } \\
\text { competitions }\end{array}$ & $\begin{array}{l}\text { On the procedure and content of } \\
\text { competition }\end{array}$ \\
\hline Law & Public Procurement Law & 2006 & $\begin{array}{l}\text { Main purpose of the Public procurement } \\
\text { regulations is to save public budget funds and make } \\
\text { it open }\end{array}$ & Impact on content and criteria \\
\hline Recommendations & Best practice rules & 2010 & & Determines quality of the brief \\
\hline Recommendations & Typical terms of competition procedure & 2007 & & Determines quality of the brief \\
\hline
\end{tabular}

Fig. 8. Impact of regulatory enactments on the terms of competitions of the research field in procedure and content categories

\section{Legal framework}

Impacts of legal framework are further analyzed as institutional practice, territorial regulations, law and recommendations by professional NGO (Fig. 8). Similar as in other European countries, there is a national cultural heritage protection institution established in Latvia, taking care for the entire heritage. The State Inspection for Heritage Protection is a direct administration institution subjected to the Ministry of Culture, implementing official policy and control in the field of cultural monument protection, performs identification and inspection of cultural heritage and registering of monuments. The activities of the inspection are based on the Convention Concerning the Protection of the World Cultural and Natural Heritage, Convention for the Protection of the Architectural Heritage of Europe, Convention for the Protection of the European Archaeological Heritage, Council of Europe's Framework Convention on the Value of Cultural Heritage for Society, law of the Republic of Latvia "On Protection of Cultural Monuments", as well as 24 other laws, 27 Cabinet Regulations and decrees, more than 70 international charters, declarations, resolutions and other international documents (State Inspection for Heritage Protection 2015b). The mission of the inspectorate is "to ensure quality of human life, preserving the cultural heritage - identifying, protecting and encouraging understanding of values", where, among other things, for the purpose of achieving of this goal the law stipulates participation of the representative of the inspectorate in the evaluation of the competitions, as well as approval of the competition results by the specially created Board of the Inspectorate, which is summoned once a month.

The development plan of the Riga historical centre and its protection zone territory (hereinafter RVC AZ TIAN $^{2}$ ) was worked out in 2006 in accordance with the applicable legislation of the Republic of Latvia and initiated as the amendments to the Riga Development plan 1995-2005. The experts confirmed that the system created by the special status has been qualitatively interpreted several times. Until then the municipal policy in regard to the preservation and development of the cultural and historical heritage, city greenery and the urban construction image of the city centre had not been implemented with sufficient detailing and consequence.

RVC AZ TIAN consists of both graphic and text parts. Regulations regarding the organization of architectural competitions are both described in the explanatory note and the intended (planned) use of the territory and as instructions in the graphic part,

\footnotetext{
2 Land use and building regulations (Teritorijas izmantošanas un apbūves noteikumi (TIAN)); Riga Historical centre and Protection zone (Rìgas Vēsturiskais centrs un tā aizsardzības zona (RVC AZ))
} 
for example, the number of building floors is determined by the designation $\left(^{*}\right)$ in the design solution as a result of an open architectural competition (RDPAD 2003). In these territories the authors of the competition design have to substantiate the solutions of the urban construction accents, number of floors and location. RVC AZ TIAN also contain special regulations for open architectural competitions in article No. 318, designed for the implementation of specific construction conceptions, as well as development of urban construction or architectural ideas, and were held in accordance with the requirements regarding the procedure of organization of construction design and territorial planning sketch competitions specified in the Cabinet Regulations (RDPAD 2003).

Recommendations have been provided both by International union of Architects (UIA 2015) and Architect's Council of Europe (ACE 2010). In addition the Latvian Association of Architects (LAoA) has achieved editing of regulatory enactments in regard to the mandatory participation of their representatives in the competition jury commissions and has also contributed to the development of two recommendation documents - typical competition brief (Balodis et al. 2011). Competition and terms of good practice regulations (LAoA 2010) (Fig. 8). Subject is also complemented by the Public Procurement Law (Saeima 2006).

\section{Decision making}

Profile of the jury and decision making is also very significant part of the procedure. A special commission is typically established for the purpose of "efficient evaluation of the proposals developed by the architects". The commission is a group of officials-experts, where the evaluation takes place in accordance with a pre-defined procedure and it is drafted as a conclusion. Whereas the jury takes the form of the dialogue and voting of the involved experts, which usually proceeds in one round and may vary depending on the functional typology and the assigned importance of the object. The responsible secretary of the jury commission usually is the representative of the person organising the competition. Typically such competition jury in the territory of RHC includes 9 persons:

- Owner of the land and/or the object - chairman of the jury commission;

- Representative of the person organising the competition - member of the jury commission;

- Two independent architects, members of the LAA;

- Representatives of the Riga City Construction Board: director or deputy director of the Construction Board; Head of the Planning department; Architect of the relevant planning region;
Head of the Riga City Inspection of Historical and Cultural Monument Protection;

- Head of the State Inspection for Heritage Protection.

The protocols of the jury conclusions were analysed in order to get a notion on the conclusion in the aspects of method interpretation. These show different ways of interpreting the jury commission method in evaluation with similar or equal criteria; the different opinions; differences of opinion qualities. The most typical are two - the individual evaluation by voting method and the individual evaluation with the discussion form, annotations and a common generalized conclusion.

1. Individual evaluation - voting. Each member of the jury commission expresses his/her view of the object in terms of 1-2 sentences and arranges the places at his/her discretion. The votes are calculated according to a simple algorithm (Table 1).

Table 1. Vote calculation algorithm

\begin{tabular}{ccccc}
\hline $\begin{array}{c}\text { Entry } \\
\text { code }\end{array}$ & $\begin{array}{c}\text { Member/ } \\
\text { Place }\end{array}$ & $\begin{array}{c}\text { Member/ } \\
\text { Place }\end{array}$ & $\ldots$ & Total \\
\hline OC 44 & $\ldots$ & $3^{\text {rd }}$ place & \\
\hline$\ldots$ & $1^{\text {st }}$ place & $\ldots$ & $4^{\text {th }}$ place & \\
\hline
\end{tabular}

The common feature of the individual opinion statements is that the opinions may differ and evaluation of the same object is contradicting. One case with evaluations of five members is taken as an example, as illustration.

2. Discussion-annotation-voting-common conclusion. Each member of the jury commission expresses his/her view on all proposals together, in 1-2 sentences, adding annotation. The votes are calculated after discussion and voting. A common reference of the jury commission is worked out, devoting a separate passage to each awarded work and adding common conclusions and recommendations at the end.

The individual opinion statements may not only differ, but their expression shows qualitative differences among the opinions themselves. Three proposals and evaluations of two members were taken as examples, for illustration.

\section{Conclusions}

The procedure of architectural competition as mandatory institutionalised requirement has emerged as a form of protection against unauthorized and unregulated development. Without overcoming formal barrier - the State Inspection of Monument Protection, the Riga City Construction Board, the Riga City Architect and the Council for Preservation and Development of Riga Historical Centre - no construction can be implemented in the centre of Riga. 
It has fulfilled its role for a certain period of time, but it has not encouraged any systematic and interconnected development in contemporary challenges of built environment in urban heritage context. No parts of mandatory competition briefs and the following protocols shows objective frame how to manage to find the one - the convincingly best solution in the complex construction situations and contradicting requirements. Criteria models are simplified for universal use and slightly adapted in every case. Regarding historical context, in most cases the criterion "compatibility of the object with the urban construction environment" is mentioned in first place, or put at the top of the hierarchy of the other criterion by bigger evaluation percentage rate.

There is no observable taxonomy change correlation between functional typology, but there is certain correlation regarding person initiating/organizing in the research selected competition briefs taxonomy. Most of the briefs are alike in content and criterions, particularly by the impact of organizer. Since all cases have been using more or less the same frame in typical content indicators, the differences concern mostly either formulation quality and resource availability or public procurement law preference, if the organizer is a public person.

The common format of competition procedures is influenced by four types of value lists: list of regulatory enactments (determines the procedure); list of jury member competences (entitled to make the choice); list of criteria (describes value); list of requirements to be met (defines conditions).

In terms of the tool, few changes over time period are noticed in criteria parameters. Interpretations in Sector D (rational use of funds) have been developed quantitatively and qualitatively. In Sector C (architectural quality) several briefs show average list extensions of additional feature formulations. In later years of the period criteria's include also such phrases as "sustainability", "green", "accessibility" and "innovation".

In terms of the mechanism, it has reached the constant frame and remained motionless. It might be a logical outcome regarding the need, the motivation and the available resources.

Selecting and evaluating of the proposal within the framework of the competition strongly depends on the competence of the jury commission in any competition of democratic flow. But particularly in urban heritage context, jury in fact has the only crucial role for interpretation of summary and results. Besides the legal framework for jury structure and decision making process, it is also indicated as dependent on the factors related to particular personalities within a jury groups. It includes skills of argumentation, motivation and in the group context - the abilities to cooperate and find compromise in the cases of viewpoint polarization. In the beginning of research period, the outcome of the competition procedure depends not so much on the dialogue, as on the mathematical distribution of votes by the jury members. Published commentaries here includes no more than one-two sentence verdict by every jury member participated. Later in the period, conclusion reports of the contest results indicate another tendency. Laconic individual estimations still exist, but frequently are followed by one-two page written compilation by a one person from the jury commission.

\section{Contribution}

The data of competitions briefs, used in preparing the publication have been obtained from the study "Practice of architectural competitions in Riga 19912013" commissioned in 2015 by the municipal agency "Bureau of the Riga City Architect". It has been worked out by L. Leitāne-Šmìdberga, PhD student of the Faculty of Architecture and Urban Planning of the Riga Technical University, based on the elaborations of her doctoral thesis "Architectural competitions in Latvia, 1859-2013".

\section{References}

ACE. 2010. Introduction to the master document for an architectural design competition by the ACE (Architect's Council of Europe) [online], [cited 2 January 2016]. Available from Internet: http://www.ace-cae.eu/uploads/tx_jidocumentsview/ADCMasterDoc.pdf

Ameloskina, N. 2008. Cultural historical environment of the historic centre of Riga: concepts of conservation (1948-2006) [online], [cited 15 December 2015]. Available from Internet: http://www.lza.lv/LZA_VestisA/69_3-4/1_Natalija\%20 Ameloskina.pdf

Andersson, J. E. 2014. Architectural competitions as a municipal instrument for innovating space for the ageing society: the dynamics of three competitions, in Proceedings of 5th International Conference on Competitions 2014, 13-14 February 2014, Netherlands. Delft, 64-80.

Balodis, U.; Lapiňš, A.; Poga, J.; Rožulapa, E.; Timofejevs, E.; Treimanis, E.; Valgums, V. 2011. Arhitektu savienības nolikums par projektu konkursiem [The Architects association regulations for Design contests]. Riga: Latvian Association of Architects.

Budže, K. 2014. The most contemporary architecture of the 21st century is the heritage of the past [online], [cited 15 December 2015]. Available from Internet: http://www.arterritory.com/lv/dzivesstils/arhitektura/3717-21._gadsimta_vislaikmetigaka_arhitektura_ir_pagatnes_mantojums/

Butters, Ch. 2011. A Holistic Method of Evaluating Sustainability [online], [cited 15 December 2015]. Available from Internet: http://www.universell-utforming.miljo.no/file_upload/idebank\%20article\%20chris\%20butters.pdf 
Cinis, A.; Dambis, J. 2003. Kad vīzija par Rīgu pārtaps īstenībā [When vision about Riga will be realized], Latvijas Vēstnesis 3.10.2003., Nr. 137 (2902) [online] [cited 15 December 2015]. Available from Internet: https://www.vestnesis.lv/ $\mathrm{ta} / \mathrm{id} / 79574$

Drexler, H.; El Khouli, S. 2012. Holistic Housing. Munich: Institut fur Architektur-Dokumentation GmbH\&Co.KG. https://doi.org/10.11129/detail.9783955531461

Eko, U. 2009. The Infinity of Lists. Milan: RCS Libri S.p.A. Bompiani.

Guilherme, P. 2014. Shall we compete?, in Proceedings of 5th International Conference on Competitions 2014, 13-14 February 2014, Netherlands. Delft, 35-63.

Jākobsone, J. 2011. Local Identity - influencing factors on cultural heritage preservation in context of sustainable development. Kuldiga case study, Scientific Journal of RTU 2: 85-89.

Kārkliņš, K. 2013. Rīga World Heritage site impact evaluation method. Riga: Riga City Council City Development Department. [online] [cited 15 December 2015]. Available from Internet: http://www.kristskarklins.com/rvc.html

Kreiner, K. 2010. Paradoxes of architectural competitions: the competition between efficiency, justice and creativity, in 26th Annual ARCOM Conference, 6-8 September 2010, Leeds, UK.

LAoA. 2010. Recomendations. Labas prakses nolikums. Rekomendācijas. [Good Practice regulations] [online], [cited 2 January 2016]. Available from Internet: http://www. latarh.lv/f/faili/ Konkursu\%20labas\%20prakses\%20nolikums.pdf

Leitāne-Šmīdberga, L. 2015. Study Architectural competitions in Riga 1991-2013 [online], [cited 15 December 2015]. Available from Internet: http://arhitekts.riga.lv/index.php?option = com_content\&view $=$ article\&id $=557$ :petijums-arhitekturas-konkursi-riga-1991-2013\&catid $=110 \&$ Itemid $=262$

Lejnieks, J.; Meiers, G.; Kukainis, I. 2015. Izstāde "Rìgas panorāma un siluets kā Eiropas mantojuma zìmes vieta" [Exibition "Riga panorama silhouette as the European Heritage Label place"], [online] [cited 15 December 2015]. Available from Internet: www.mantojums.lv

Menon, C.; Vandenburgh, D. 2014. Who or what wins an architectural competition?, FORMakademisk 7(1):1-19. https://doi.org/10.7577/formakademisk.822

Ronn, M. 2011. Architectural quality in competitions. A dialogue based assessment of design proposals, FORMakademisk 4(1):100-115.

Ronn, M. 2014. Choosing architects for competitions- experiences from the selection of design teams in Sweden, FORMakademisk 7(1):1-17

Ronn, M.; Kazemian, R. 2007. Key concepts, criteria and quality judgement in architecture, in Nordic Conference: Beyond Dichotomies, 16-18 August 2007, Oulu, Finland.

RDPAD. 2003. Teritorijas izmantošanas un apbūves noteikumi (TIAN). Rìgas Vèsturiskais centrs un tā aizsardzības zona (RVC AZ) [Land use and building regulations. Riga Historical centre and Protection zone]. Regulation by Riga City Council City Development Department. [online], [cited 15 December 2015]. Available from Internet: www.rdpad.lv

Saeima. 2003. Rīgas vēsturiskā centra saglabāšanas un aizsardzíbas likums [Riga Historical Centre Preservation and Protection Law] [online], [cited 15 December 2015]. Available from Internet: http://likumi.lv/doc.php?id = 76001
Saeima. 2006. Publiskā iepirkuma likums [Public procurement law] [online], [cited 15 December 2015]. Available from Internet: http://likumi.lv/doc.php?id = 133536

Salmon, L. 2016. UNESCO World Heritage List [online], [cited 7 November 2016]. Available from Internet: http://www. thesalmons.org/lynn/world.heritage.html

State Inspection for Heritage Protection. 2014. Pasaules mantojuma vietas retrospektīvais ìpašas nozìmes un universālās vērtības pamatojums. Rīgas vēsturiskais centrs [World Heritage Sites retrospective of outstanding universal value and justification. Historic Centre of Riga] [online], [cited 15 December 2015] Available from Internet: http://www.rpr.gov.lv/uploads/filedir/ IAS\%20un\%20AP\%20izstrade/Parskats/RPR\%20Parskats\%20 par\%20IAS\%20un\%20AP\%20izstradi.pdf

State Inspection for Heritage Protection. 2015a. Public administration of cultural heritage [online], [cited 12 December 2015]. Available from Internet: http://mantojums.lv/lv/pakalpojumi/

State Inspection for Heritage Protection. 2015b. About inspection [online], [cited 12 December 2015]. Available from Internet: http://mantojums.lv/lv/par-inspekciju/

UIA. 2015. Competition Guide. UNESCO Standard regulations for international competitions in architecture and town planning [online], [cited 2 January 2015]. Available from Internet: http://portal.unesco.org/en

UNESCO. 2011. Recommendation on the Historic Urban Landscape [online], [cited 15 December 2015]. Available from Internet: http://www.raa.se/app/uploads/2013/05/ SuHiTo-Project-Report-Eng.pdf

Volker, L. 2010a. Deciding about design quality. Value judgements and decision making in the selection of architects by public clients under European tendering regulations. Leiden: Sidestone Press.

Volker, L. 2010b. Design a design competition: the client perspective, in conference Design \& Complexity, 7-9 July 2010, Montréal, Canada.

Volker, L.; Lauche, K.; Heintz, J. L.; de Jonge, H. 2008. Deciding about design quality: design perception during a European tendering procedure, Design Studies, 29: 387-409. https://doi.org/10.1016/j.destud.2008.03.004

WHC. 1997. World Heritage Committee List No. 852 [online], [cited 15 December 2015]. Available from Internet: http://www. unesco.lv/lv/unesco-latvija/unesco-latvija-1/

\section{ILZE MIKELSONE}

is graduated as architect (2000) and received the Professional Master Degree in Architecture in the Faculty of Architecture and Urban Planning, Riga Technical University (2012). Since 2012 she proceeds as doctoral student within the same institution. Her main research interest affects challenges and controversies in Architecture of XXI in aspects of value hierarchies. Ilze has worked as an architect in architectural offices "SZK arhitekti" (Latvia) and "Van den Oever, Zaaijer \& Partners" (Nederland). Since 2008 runs private architectural practice.

Ilze is the author of the following publications: Custom-Made Patchwork Landscape: Entrepreneurial and Private Regionalism. Mokslas - Lietuvos ateitis, Volume 2014, 6(3), pp. 290-302; ISSN: 2029-2341, DOI: 10.3846/mla.2014.041;

Quantitative and qualitative parameters of awards in architecture and construction industries of Latvia, Mokslas - Lietuvos ateitis, Volume 2015, 7(1), pp. 89-100, DOI: 10.3846/mla.2015.724. 